Marcin J. PiąTKOWSKI

Cracow University of Economics, Poland

\title{
Analysis of Investment Activities of Enterprises in Poland
}

\begin{abstract}
The impact on the development of the economy and enterprises themselves is made possible by investments as they are one of the main components of GDP. An increase in enterprise investments demonstrates the good financial condition of economic entities, is a positive signal about the state of the economy and gives information about its development. The subject of this article is the impact of enterprises on the economy and its importance in Poland by analysing both investment itself and the investment rate. The analysis was carried out at a regional level as well as in relation to other EU member states. The aim is to analyse the investment activities of Polish enterprises, with particular emphasis on the change as well as their size and type. The research is based on a critical analysis of the literature and an analysis of secondary statistical data, covering the period from the first full EU program from 2007, and extended in accordance with the $\mathrm{n}+2$ funding rule until 2015. The analyses show that despite growing investment among Polish enterprises, compared to the rest of the EU, the value of expenditure on fixed assets is still low as the average value made in the private sector among EU countries is 70\% higher. At the same time, the growing level of investment value among private businesses over the nine years should be emphasized. There is also a very large regional variation in the level of investment growth per working-age capita over the period considered.
\end{abstract}

Keywords: enterprise; investment activities; investment rate; Poland; regional comparative analysis; SMEs; the economy

Received: 25 October 2019

Accepted: 12 May 2020

\section{Suggested citation:}

Piątkowski, M.J. (2020). Analysis of Investment Activities of Enterprises in Poland. Przedsiębiorczość - Edukacja [Entrepreneurship - Education], 16(2), 225-238. doi: 10.24917/20833296.162.18

\section{Introduction}

A company's investment activity is a crucial element for its development and to build a competitive advantage. The scale of expenditure translates into the level of development and thus the ability to compete with other businesses and, as a result, to obtain economic benefits. It should be remembered that enterprises, and especially in the SME 
sector, are of significant importance for the economy, especially for the labour market, the level of economic development, as a source of innovation, and supplying state and local government budgets with tax revenues. At the same time, enterprises as an element of the environment are influenced by both national and global economies. Development and investment opportunities also depend therefore on their regional situation as well as available resources. For this reason, research undertaken to find out the investment of enterprises at both regional and national level should be considered essential.

The article aims to analyse the investment activities of Polish enterprises with an emphasis on the change as well as their regional size and type. The results of the analysis are presented from a regional perspective, expanded to include the results of research on a national scale, as well as concerning other EU member states. The analysis refers to the years 2007-2015 and covers the first period of Poland's full participation in the EU with the implementation of structural funds. The work is theoretical and empirical, and the research was based on a critical analysis of the literature and of existing data, including Eurostat, BDL and CSO, as the basis for the empirical part of the study. A descriptive approach was used in data analysis.

\section{The importance of investment in business operations}

A company's investment activity is a crucial element for its development and building a competitive advantage. At the same time, investments are an essential factor affecting the country's economic growth and are a primary component of GDP.

The aim of activities undertaken in the process of managing a business should be to strive to maximise the income of its owners and increase the market value of the enterprise (Borowiecki, 2009; Obłój, 2007; Suszyński, 2007). Obtaining the intended effect is possible by making development decisions, which include investments, treating them as one of the most important ways of increasing a company's capital. For this reason, a unique role is assigned to investment processes leading to an effect on its future economic situation (Czyżowska, 2014; Żurek, 2003). Investment decisions play a vital role in its further functioning and development associated with the freezing of funds over a long time and whose effects will be observable only in the long term, which in turn should result in an improvement of a company's competitive position (Bień, 2000; Wildowicz-Giegel, 2013), considering inflation and investment risk (Reilly, Brown, 2011). This means that investments should be combined directly to develop an enterprise defined as more favourable than the current one.

In public statistics, the concept of investment is used. This is understood as "financial or tangible expenditure, the purpose of which is to create new fixed assets or the improvement (reconstruction, extension, reconstruction or modernisation) of existing fixed assets, as well as expenditure on so-called 'initial investments' (GUS, 2018). This approach was also adopted in this article.

The variety of elements from its environment affecting the functioning of enterprises means that each investment has its character. The investor expects benefits as a result of capital involvement, however, the effects are postponed (Firlej, 2019; Rębilas, 2014). The expected impacts are obtained by increased competitive advantage or counteracting the loss of its current market position, and the enterprise can reap benefits in three areas: economic, organisational and social (Rogowski, 2011). 
In the economic dimension, the benefits of investment are observable by increasing sales revenues, improving the quality of products and services offered, reducing the company's operating costs, and by minimising risk in business operations. In the organisational dimension, the company can gain benefits from increased flexibility to change its environment and a faster response to current and future needs. In the social dimension, benefits can be seen based on the organisational culture created in the enterprise, through the development and excellence of employees, resulting in increased integration with the employer, while building and improving motivation (Piątkowski, 2013; Rębilas, 2014).

It should be emphasised that in the absence of investment an enterprise does not grow, and this threatens liquidation or bankruptcy. This is a consequence of the fact that stagnation in the development of a company is equivalent to regression against the developing environment. Therefore, the efficient operation of an enterprise in the long run without investment or planning is impossible. At the same time, the development of regions and entire economies is not possible without capital expenditure by enterprises which play an essential role in building a competitive economy and contribute significantly to GDP growth (Piątkowski, 2010, 2020). For this reason, it is crucial to continually monitor and analyse investment activities undertaken in the enterprise sector, the subject of the research presented in this article.

\section{The enterprise investment rate in Poland and the EU}

Despite growing investment among Polish enterprises in the analysed period against the background of the rest of the EU, the value per fixed asset is still low (Figure 1). The average EU investment in the private sector per enterprise in 2015 was 51000 EUR which is up to $70 \%$ higher than in Poland. Such a high level is the effect of high expenditure

Figure 1. Investments in fixed assets per company in the EU in 2015 (in thousands of EUR)

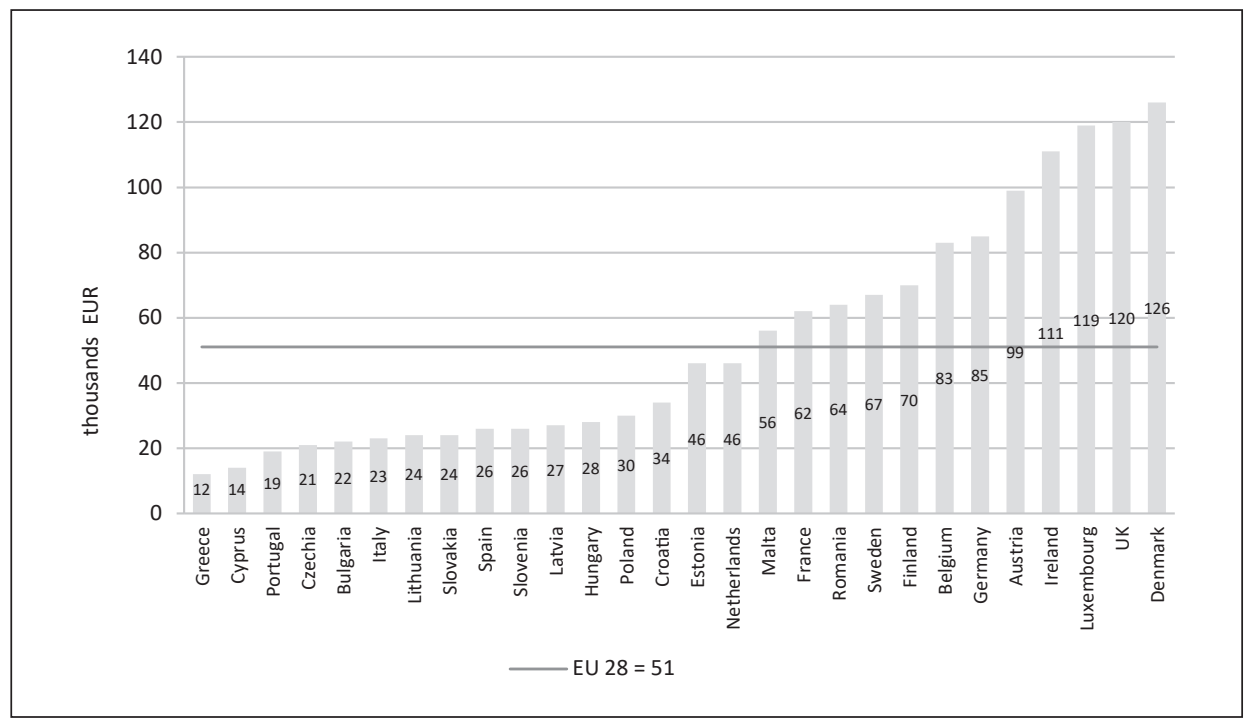

Source: Eurostat (sbs_na_sca_r2) 
in the so-called "old union" in which countries such as Denmark, United Kingdom, Luxembourg, Ireland, Austria, Germany, Belgium dominate, and where enterprises invest on average more than 80000 EUR per entity.

Among EU countries that became members after 2004, Poland is fifth after Croatia, Estonia, Malta and Romania. Greece, Cyprus and Portugal are in the worst situation with an average level of investment in 2015 of less than 20000 EUR per company. In absolute terms, Polish enterprises place the country in 6th place, however, the amounts of money allocated for investments in the private sector move Poland to a distant 16th place. Many studies emphasise this position of Polish enterprises, especially in the SME sector, relative to other European companies. It should be highlighted that making investments in new and technologically advanced fixed assets requires capital that enterprises lack. Thus, the process of modernising Polish companies will take longer. Therefore, to expect a better situation for SMEs, it is necessary to support both their day-to-day functioning and make appropriate facilities to enable market expansion. An essential role in helping enterprises is played both at national and local government levels (Skica, Bem, Żygadło, 2013). The critical issue is the continuous introduction and improvement of financial instruments to allow easier access to capital which translates into the commercialisation of more technologically advanced products (services) or the machines and devices themselves, as well as technologies enabling more effective production.

When analysing the investment activity of enterprises, it is also essential to pay attention to the investment rate indicator which reflects the ratio of gross fixed capital formation to GDP. The gross value of fixed assets corresponds to a value equal to the expenditure for their purchase or production without reducing the value of consumption (GUS, 2016b). The increase in the value of the indicator shows the growing propensity of enterprises to invest, contributing to increasing labour productivity, as well as possible increases in employee remuneration.

Figure 2. The total investment rate in Poland and across the European Union in 2015 (\%)

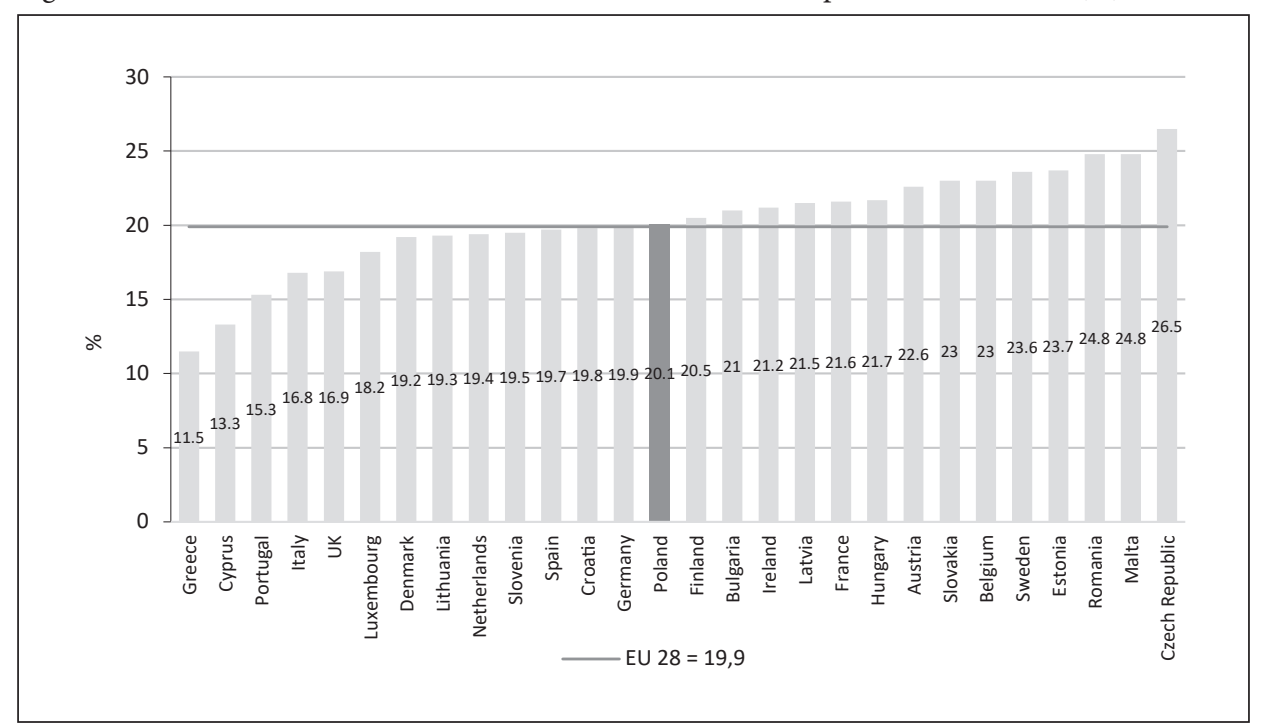

Source: author based on Eurostat (code: tec00011) 
Gross fixed capital formation increases the value of fixed assets. It includes expenditure on buildings and the renovation of fixed assets, machinery and equipment, means of transport, as well as an increase in intangible assets with a useful life of longer than one year (including property rights, copyright, rights to projects, inventions, patents, trademarks, licenses and the costs of completed development and goodwill). They do not include other expenses, i.e. those covering the initial investments, interest on loans and borrowings, as well as additional costs related to their implementation that do not increase the value of fixed assets. Expenditure on fixed assets together with other spending is defined as investment expenditure (GUS, 2016a).

In 2015, the level of gross fixed capital formation in Poland in relation to GDP amounted to $20.1 \%$ putting it in 15th place, in the middle of the EU ranking. This investment rate also puts Poland in the group of countries that achieved a higher result than the EU average of $19.9 \%$ (Figure 2). Throughout the period under review, the level of investment in Poland remained relatively stable, oscillating around 20\%, with the highest figures in 2007-2008 (22.5\% and 23.1\% respectively) before the global financial crisis. However, the lowest value was recorded in $2013(18.8 \%)$ as a result of reduced investment in the public sector (by $0.6 \mathrm{pp}$ - percentage points - compared to 2012), a result of the end to the EU programming period of 2007-2013, as well as reduced investments among households (by $0.4 \mathrm{pp}$ year to year). Throughout the period under review, the level of public sector investment was always higher than the EU-28 average, but this was never achieved in the private sector among either enterprises or households (Table 1).

Table 1. The investment rate in the economy in Poland and the EU-28 in 2007-2015 (\%)

\begin{tabular}{|c|c|c|c|c|c|c|c|c|c|}
\hline Specification & 2007 & 2008 & 2009 & 2010 & 2011 & 2012 & 2013 & 2014 & 2015 \\
\hline Poland & 22.5 & 23.1 & 21.4 & 20.3 & 20.7 & 19.8 & 18.8 & 19.7 & 20.1 \\
\hline UE-28 & 22.9 & 22.8 & 20.8 & 20.4 & 20.5 & 20.1 & 19.6 & 19.8 & 19.9 \\
\hline \multicolumn{10}{|c|}{ Public sector investment rate } \\
\hline Poland & 4.5 & 4.8 & 5.0 & 5.6 & 5.9 & 4.7 & 4.1 & 4.5 & 4.4 \\
\hline UE-28 & 3.2 & 3.4 & 3.7 & 3.5 & 3.3 & 3.0 & 3.0 & 3.0 & 2.9 \\
\hline \multicolumn{10}{|c|}{ Private sector investment rate } \\
\hline Poland & 18.0 & 18.3 & 16.4 & 14.7 & 14.8 & 15.1 & 14.7 & 15.2 & 15.7 \\
\hline UE-28 & 19.7 & 19.4 & 17.1 & 16.9 & 17.2 & 17.0 & 16.6 & 16.8 & 17.0 \\
\hline \multicolumn{10}{|c|}{ a) including enterprises } \\
\hline Poland & 12.4 & 12.5 & 11.0 & 9.7 & 10.0 & 10.1 & 10.1 & 10.4 & 10.9 \\
\hline UE-28 & 12.9 & 13.0 & 11.4 & 11.3 & 11.8 & 11.8 & 11.6 & 11.8 & 12.0 \\
\hline \multicolumn{10}{|c|}{ b) including households } \\
\hline Poland & 5.6 & 5.8 & 5.4 & 5.0 & 4.8 & 5.0 & 4.6 & 4.8 & 4.8 \\
\hline UE-28 & 6.8 & 6.4 & 5.7 & 5.6 & 5.4 & 5.2 & 5.0 & 5.0 & 5.0 \\
\hline
\end{tabular}

Source: author based on Eurostat (code: tsdec210)

It should be noted, however, that the investments of the entire private sector account for around $80 \%$ of the total level of expenditure on fixed assets relative to GDP. Nevertheless, this share gradually decreased in 2007-2011, reaching a minimum of $71.5 \%$ although from 2012 there was a gradual increase to approach the base value by 2015, although lower by $1.9 \mathrm{pp}$ than at the beginning of the period under review. Considering the level of 
investment for enterprises, the highest level of deviation from the EU average occurred in 2010-2014 (between 1.4-1.8 pp). The highest was in 2011, although overall there was an increase of $0.3 \mathrm{pp}$ relative to 2010 . The highest share of outlay on fixed assets relative to GDP of the enterprise sector occurred in 2007-2008, i.e. at the beginning of the EU period when public sector investments had not yet been fully implemented due to ongoing tender procedures.

In the regional system as of the end of 2015, the highest figures were found in Opolskie Voivodeship, followed by Podlaskie and Kujawsko-Pomorskie. The lowest after Małopolskie Voivodeship were Śląskie, Świętokrzyskie and Dolnośląskie (Table 2). Among Polish regions, in five (incl. two in eastern Poland) there was an increase in the index at the end of 2015 compared to 2007 (Opolskie - 36\%, Kujawsko-Pomorskie - 11\%, Lubelskie - 9\%, Zachodniopomorskie $-2 \%$, Podlaskie - 1\%). On the other hand, in eleven voivodeships, there was a decrease compared to the base year. The highest increase was in Opolskie by $36 \%$ (i.e. 7 pp), and the most significant decrease in Śląskie by $20 \%$ (i.e. 4.3 pp), and Dolnośląskie and Łódzkie by $18 \%$ and $17 \%$ respectively.

Table 2. Investment rate in voivodeships in 2007-2015 (\%)

\begin{tabular}{|r|l|c|c|c|c|c|c|c|c|c|}
\hline No & \multicolumn{1}{|c|}{ Voivodeship } & $\mathbf{2 0 0 7}$ & $\mathbf{2 0 0 8}$ & $\mathbf{2 0 0 9}$ & $\mathbf{2 0 1 0}$ & $\mathbf{2 0 1 1}$ & $\mathbf{2 0 1 2}$ & $\mathbf{2 0 1 3}$ & $\mathbf{2 0 1 4}$ & $\mathbf{2 0 1 5}$ \\
\hline 1 & Opolskie & 19.4 & 18.4 & 20.5 & 20.7 & 19.7 & 17.6 & 18.6 & 20.5 & 26.4 \\
\hline 2 & Podlaskie & 23.6 & 24.4 & 21.2 & 22.0 & 25.8 & 22.0 & 20.7 & 24.3 & 23.9 \\
\hline 3 & Kujawsko-Pomorskie & 20.5 & 23.2 & 23.9 & 22.2 & 21.7 & 18.5 & 17.6 & 19.8 & 22.8 \\
\hline 4 & Warmińsko-Mazurskie & 23.6 & 24.0 & 21.3 & 22.6 & 24.5 & 23.2 & 19.2 & 19.7 & 22.4 \\
\hline 5 & Pomorskie & 25.6 & 27.1 & 30.0 & 21.5 & 20.9 & 21.6 & 19.6 & 20.8 & 21.7 \\
\hline 6 & Zachodniopomorskie & 21.0 & 23.9 & 21.4 & 19.9 & 19.9 & 21.5 & 23.5 & 21.5 & 21.4 \\
\hline 7 & Podkarpackie & 21.8 & 21.8 & 21.6 & 24.4 & 28.5 & 26.3 & 23.9 & 22.5 & 21.0 \\
\hline 8 & Lubelskie & 19.1 & 21.3 & 20.9 & 20.7 & 23.1 & 20.9 & 20.0 & 21.4 & 20.8 \\
\hline 9 & Lódzkie & 25.0 & 24.7 & 21.3 & 20.5 & 22.4 & 23.2 & 21.3 & 20.1 & 20.7 \\
\hline 10 & Małopolskie & 23.2 & 22.3 & 19.2 & 20.1 & 20.3 & 19.9 & 18.6 & 19.1 & 20.4 \\
\hline 11 & Wielkopolskie & 21.4 & 23.4 & 19.5 & 19.5 & 19.4 & 19.3 & 16.7 & 18.8 & 19.8 \\
\hline 12 & Lubuskie & 23.0 & 21.6 & 19.4 & 29.1 & 29.1 & 21.7 & 19.5 & 17.0 & 19.7 \\
\hline 13 & Mazowieckie & 23.3 & 24.2 & 21.3 & 19.0 & 18.5 & 18.2 & 17.9 & 20.2 & 19.5 \\
\hline 14 & Dolnośląskie & 23.4 & 22.8 & 21.6 & 18.9 & 19.3 & 18.8 & 19.6 & 19.8 & 19.1 \\
\hline 15 & Swiętokrzyskie & 18.4 & 21.4 & 22.4 & 24.0 & 22.1 & 21.1 & 16.7 & 16.4 & 18.1 \\
\hline 16 & Slląskie & 21.3 & 21.1 & 20.3 & 18.3 & 19.1 & 17.2 & 17.1 & 17.4 & 17.0 \\
\hline & Poland & 22.5 & 23.1 & 21.4 & 20.3 & 20.7 & 19.8 & 18.8 & 19.8 & 20.1 \\
\cline { 2 - 8 }
\end{tabular}

Source: author based on BDL CSO data

\section{Enterprise investments - regional analysis}

In terms of investment, taking into account sectors of the national economy and the regions in which private sector investment prevailed are Opolskie, Wielkopolskie, Dolnośląskie, Łódzkie, and Mazowieckie (from 81.4\% to 64.1\%). In contrast, in four voivodships (Zachodniopomorskie, Podlaskie, Kujawsko-Pomorskie, and Świętokrzyskie), private sector enterprise investments constituted no more than 55\% (Figure 3). In the case of Warmińsko-Mazurskie Voivodeship, the public sector exceeded the level of expenditure 
on investments (51.6\%) over expenses by the private sector, the only one where this happened in Poland.

A significant increase in the share of the public sector in the value of total investment in most voivodeships occurred in 2009, i.e. since the full implementation of the financial program 2007-2013 (Figure 4). In the national economy, over the nine years starting from 2007, the share of investment made by private enterprises in relation to

Figure 3. Share of investment by sector of the national economy in 2015

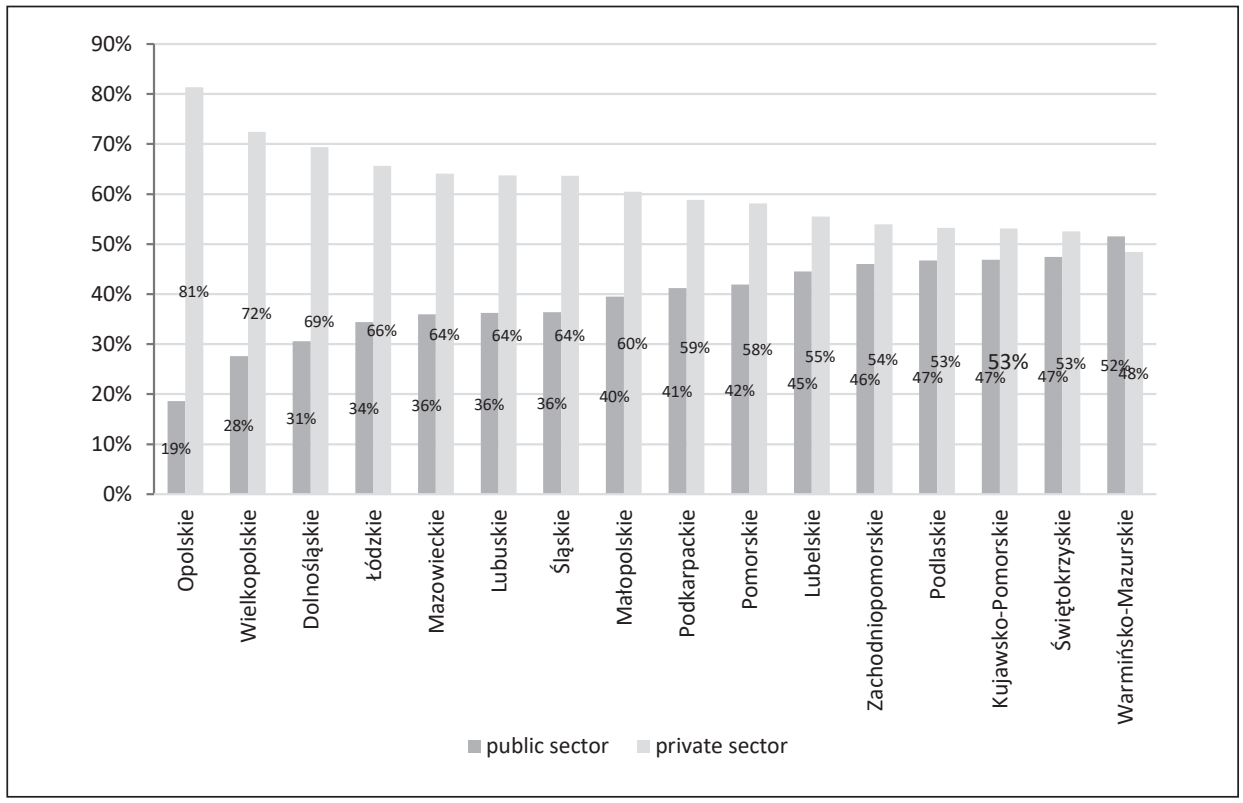

Source: author based on BDL CSO

Figure 4. Share of investment by sectors of the national economy in Poland in 2007-2015

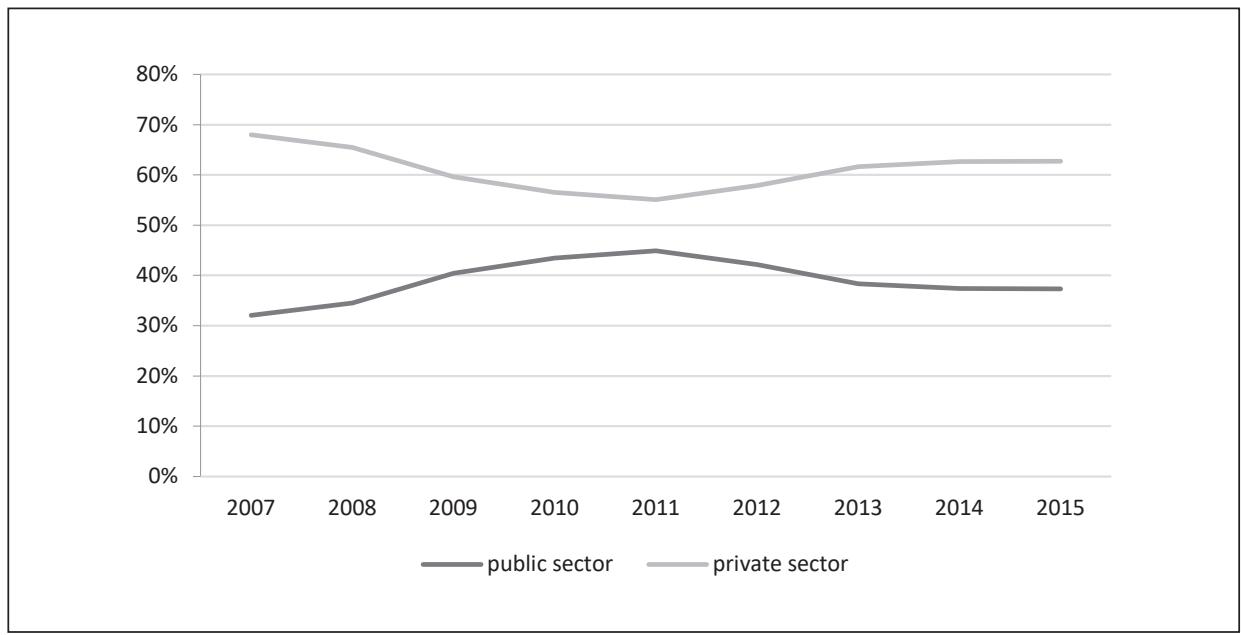

Source: author based on BDL CSO 
total expenditure decreased by $35.3 \mathrm{pp}$ in favour of the public sector. This was due to the implementation of European funds and increased public investments.

Considering the level of investment in the private and public sectors in relation to all investments in the economy, two events that affect this relationship should be remembered. In the years 2010-2011, i.e. immediately after the global financial crisis, entrepreneurs could again return to implementing investments in a bid for a better competitive position for their companies compared to the period when they had limited opportunities. The second moment when there was a drop in the investment rate indicator was caused by the effect of reduced expenditure on the public investment side, as well as the lack of recovery in the enterprise sector, after the eurozone crisis in 2014. The lower level of public investment was associated with the exhaustion of available funding under the EU 2007-2013 program and the closing of investment projects from this period.

Since 2009, there was a growing trend in the share of private enterprise in total investments, and increasing investment value among them. The total investment in Poland in 2015 amounted to PLN 200.6 billion and was 9.5\% higher than a year before. If compared to 2007 , it was an increase of as much as $39 \%$. Considering expenditure in companies by their size, large enterprises (55\%) had a significant share for many years amounting to PLN 110.7 billion. The value of the SME sector was below PLN 90 billion dominated by medium-sized enterprises (45\%), followed by micro- and small-scale enterprises $(33 \%$ and $22 \%$, respectively).

However, among the newest, up to five years old, an average decrease in the number of investing businesses was found. The most substantial reduction over eight years was recorded in four-year-old companies by $12.7 \mathrm{pp}$, and the lowest, by five-year-old companies, by 6.4 pp (GUS, 2013). When grouping companies by age throughout the entire period, for the first three years of existence, on average, only every third enterprise $(28 \%)$ made any investment. The main reason was the lack of financial resources. Besides, when starting operations and making initial investments, new enterprises (not taking into account start-ups and companies based on a rapid growth model) need about 2-3 years to develop a market position that allows them to think about further investments.

In the first six voivodeships listed in Table 3, there was entrepreneurial capital expenditure and expenditure on the purchase of fixed assets with a total value of PLN 145 billion, representing 75\% of investment expenditure nationwide. Except for Małopolskie, in all these regions expenditure in the SME sector was lower than that in large enterprises. However, in eleven voivodeships, the share of the SME sector was greater than in large enterprises.

Table 3. Investment and expenses for the purchase of fixed assets by enterprise size classes of in voivodeships in 2015 (PLN million)

\begin{tabular}{|r|l|r|r|r|r|r|r|}
\hline No & \multicolumn{1}{|c|}{ Voivodeship } & \multicolumn{1}{c|}{ Total } & \multicolumn{1}{c|}{ SME } & \multicolumn{1}{c|}{ Micro } & \multicolumn{1}{c|}{ Small } & Medium & \multicolumn{1}{c|}{ Large } \\
\hline 1 & Mazowieckie & 64781.9 & 22092.3 & 8805.6 & 3723.2 & 9563.5 & 42689.6 \\
\hline 2 & Śląskie & 21696.0 & 9443.4 & 2400.4 & 2585.0 & 4458.0 & 12252.6 \\
\hline 3 & Wielkopolskie & 20211.3 & 8997.9 & 3398.9 & 1963.3 & 3635.7 & 11213.3 \\
\hline 4 & Łódzkie & 15028.3 & 5495.1 & 1817.2 & 1084.1 & 2593.8 & 9533.2 \\
\hline 5 & Małopolskie & 14131.3 & 7241.7 & 2179.0 & 1841.5 & 3221.3 & 6889.6 \\
\hline 6 & Dolnośląskie & 13797.4 & 5704.2 & 1386.2 & 1441.5 & 2876.5 & 8093.2 \\
\hline
\end{tabular}




\begin{tabular}{|r|l|r|r|r|r|r|r|}
\hline 7 & Pomorskie & 10731.5 & 6142.1 & 1655.5 & 1364.6 & 3122.1 & 4589.4 \\
\hline 8 & Kujawsko-Pomorskie & 7482.5 & 4641.4 & 1445.8 & 1034.4 & 2161.3 & 2841.1 \\
\hline 9 & Zachodniopomorskie & 6326.4 & 4401.1 & 1662.6 & 731.3 & 2007.3 & 1925.3 \\
\hline 10 & Lubelskie & 5676.7 & 2950.6 & 1164.0 & 812.2 & 974.3 & 2726.2 \\
\hline 11 & Podkarpackie & 5468.9 & 3242.3 & 1015.3 & 735.2 & 1491.8 & 2226.6 \\
\hline 12 & Lubuskie & 3271.8 & 1823.6 & 565.3 & 420.9 & 837.4 & 1448.2 \\
\hline 13 & Warmińsko-Mazurskie & 3233.4 & 2159.0 & 581.8 & 507.2 & 1070.0 & 1074.4 \\
\hline 14 & Podlaskie & 3045.6 & 1916.7 & 624.3 & 559.9 & 732.6 & 1128.9 \\
\hline 15 & Opolskie & 2877.2 & 1830.8 & 603.6 & 483.0 & 744.2 & 1046.4 \\
\hline 16 & Swiętokrzyskie & 2857.8 & 1805.6 & 421.6 & 509.0 & 875.0 & 1052.2 \\
\hline
\end{tabular}

Source: author based on BDL CSO data

Structurally, large enterprises have a dominant role in terms of the value of investments (55\%) among all businesses according to size. Within the SME sector itself, medium-sized enterprises had a dominant share (45\%), followed by micro- and small-scale businesses (33\% and $22 \%$, respectively). In six voivodeships in which the level of investment expenditure in absolute terms was highest, the share of the SME sector did not exceed 50\%. In turn, in the regions at the other end of the spectrum, the SME sector reached 60-70\%.

Changes to capital expenditures in 2015 relative to the beginning of the audited period amounted to $40 \%$. Over the nine years, a significant level of capital invested in fixed assets in micro-enterprises was observed, increasing by $62 \%$ nationwide. The level of investments per enterprise in Poland in the SME sector also increased from 38800 PLN in 2007 to 47000 PLN at the end of 2015 (an increase of 21\%).

In terms of the type of investment, the largest share was investments in industry (52.6\%, which corresponds to PLN 105.6 billion) (Figure 5) with the most significant percentage in manufacturing (57\%).

Economic activity, especially in industrial processing, plays a vital role in the development of the economy. Therefore, it is not surprising that it is in this area that entrepreneurs made the highest investment. The following five sectors (transport and storage, trade, construction, real estate market services, information and communication) constituted a total of $37.8 \%$ of all expenditure in the enterprise sector. Together with 'industry', they form the dominant sector of the economy, with over $90 \%$ participation in business investments in Poland.

It is also worth paying attention to another indicator presenting the strength of business investment which is in the form of the value of the investment in non-financial enterprises per working-age inhabitant, which is shown in Table 4.

Per capita investment across the country in 2015 exceeded 8300 PLN which was almost PLN 800 more than a year previously, but nearly PLN 2500 more than in 2007, i.e. $42 \%$ more. It shows how high the level of investment was in enterprises over the nine years.

The level of investment growth in enterprises would be equally high, even taking into account that the number of people of working age in Poland would drop by 543000 to $24,002,000$. Assuming that in 2015 the number at working age was identical to that in 2007, the level of investment per person would be PLN 185 lower. This means that investment by enterprises per inhabitant at the working-age of PLN 8173 had increased by $39 \%$ 
Figure 5. Share of investment in non-financial enterprises by $\mathrm{PKD}^{\star} 2007$ sectors in Poland (\%)

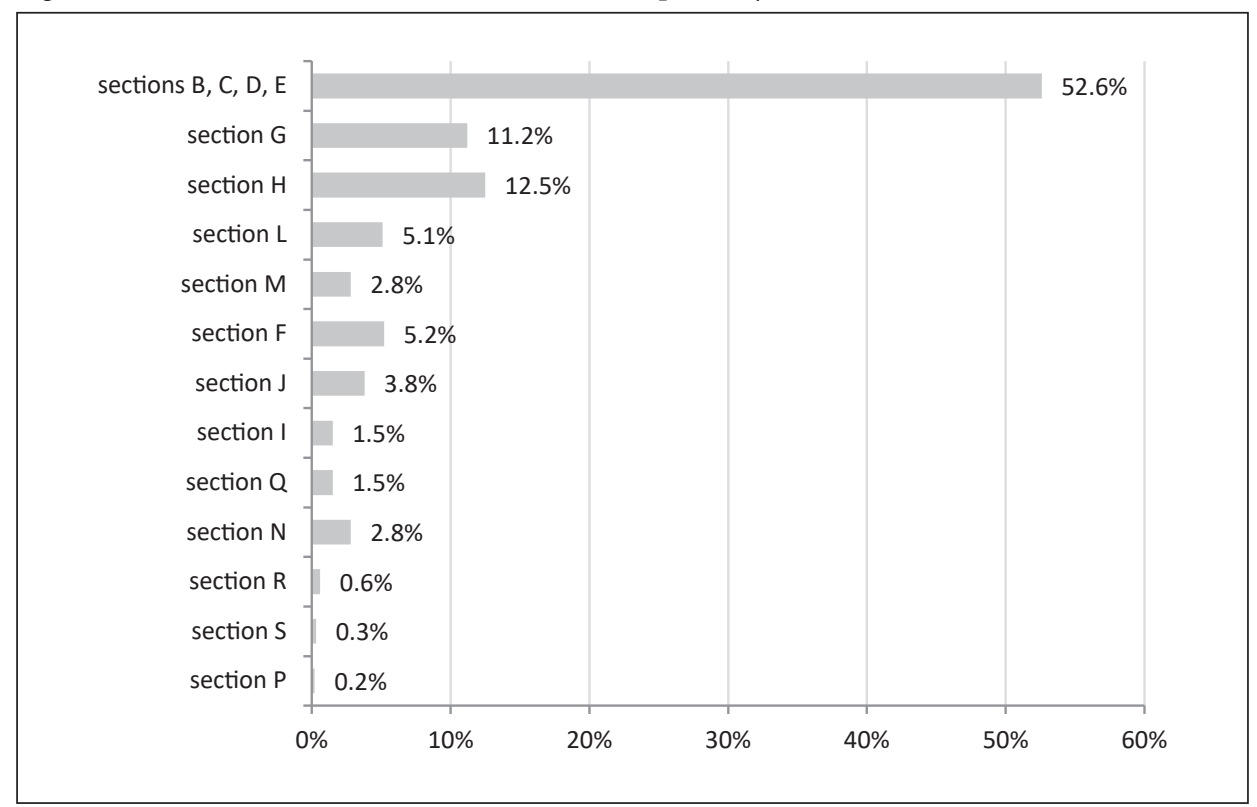

* PKD 2007 sectors: B, C, D, E - collectively referred to as industry (B - mining, C - industrial processing, $\mathrm{D}$ - production and supply of electricity, gas, steam and hot water, E - water supply; sewage and waste management; reclamation), $\mathrm{G}$ - trade in motor vehicles and their repair, $\mathrm{H}$ - transport and storage, $\mathrm{L}$ - real estate market services, $\mathrm{M}$ - professional, scientific and technical activities, $\mathrm{F}$ - construction, J - information and communication, I - accommodation and gastronomy, Q - health care and social assistance, $\mathrm{N}$ - administration and support activities, $\mathrm{R}$ - culture, entertainment and recreation, $\mathrm{S}$ - other service activities, $\mathrm{P}$ - education

Source: author based on BDL CSO data

Table 4. Investment in non-financial enterprises per capita at working age (PLN)

\begin{tabular}{|r|l|r|r|r|r|r|r|r|r|r|}
\hline No & \multicolumn{1}{|c|}{ Voivodeship } & $\mathbf{2 0 0 7}$ & $\mathbf{2 0 0 8}$ & $\mathbf{2 0 0 9}$ & $\mathbf{2 0 1 0}$ & $\mathbf{2 0 1 1}$ & $\mathbf{2 0 1 2}$ & $\mathbf{2 0 1 3}$ & $\mathbf{2 0 1 4}$ & $\mathbf{2 0 1 5}$ \\
\hline 1 & Mazowieckie & 12788 & 14397 & 12818 & 12230 & 13746 & 13421 & 15233 & 18475 & 19734 \\
\hline 2 & Lódzkie & 5817 & 6655 & 5473 & 5754 & 5987 & 5631 & 5584 & 7679 & 9819 \\
\hline 3 & Wielkopolskie & 5629 & 6546 & 5365 & 6760 & 7600 & 6868 & 6317 & 8111 & 9290 \\
\hline 4 & Śląskie & 6025 & 6239 & 5636 & 5057 & 6683 & 6833 & 6850 & 6830 & 7590 \\
\hline 5 & Dolnośląskie & 6286 & 6090 & 5398 & 5862 & 6153 & 6227 & 7044 & 7328 & 7566 \\
\hline 6 & Pomorskie & 6090 & 7241 & 9323 & 6553 & 6829 & 6533 & 6355 & 7039 & 7472 \\
\hline 7 & Małopolskie & 4985 & 5251 & 4429 & 4506 & 5751 & 5683 & 5583 & 5733 & 6710 \\
\hline 8 & Zachodniopomorskie & 4672 & 5396 & 3918 & 3380 & 3644 & 4181 & 5749 & 4870 & 5860 \\
\hline 9 & Kujawsko-Pomorskie & 3721 & 4632 & 4140 & 3582 & 3728 & 3277 & 4016 & 4615 & 5716 \\
\hline 10 & Lubuskie & 4045 & 4370 & 3314 & 3215 & 3402 & 3366 & 3594 & 3334 & 5091 \\
\hline 11 & Opolskie & 3174 & 3189 & 3446 & 3621 & 3813 & 3560 & 3514 & 3797 & 4527 \\
\hline 12 & Lubelskie & 2314 & 2947 & 2927 & 3538 & 4373 & 3965 & 4099 & 5018 & 4275 \\
\hline 13 & Podkarpackie & 3244 & 3613 & 2939 & 3100 & 3673 & 3481 & 3874 & 4120 & 4065 \\
\hline 14 & Podlaskie & 3283 & 3544 & 2789 & 2847 & 4280 & 3340 & 3266 & 3688 & 4059 \\
\hline 15 & Świętokrzyskie & 3722 & 4989 & 4316 & 4616 & 4597 & 4480 & 3421 & 3658 & 3660 \\
\hline 16 & Warmińsko-Mazurskie & 3044 & 3002 & 2475 & 2698 & 2944 & 2430 & 2379 & 3089 & 3525 \\
\hline
\end{tabular}

Source: author based on BDL CSO data 
compared to 2007 (i.e. by 3 pp lower than with real calculation). Despite this correction, the high value of investments made by business owners should be emphasised, especially in fixed assets including machinery and equipment as well as tools, buildings, and means of transport.

At the same time, considerable regional diversity is found in the level of investment growth per capita at working age over the years 2007-2015, where the range in absolute terms is as much as 7000 PLN. The most significant increase occurred in Lubelskie Voivodeship (85\%, i.e. almost PLN 2000), and by Mazowieckie at nearly PLN 7000 (54\%). At the other extreme were the regions where changes in values were not so substantial. They include Warmińsko-Mazurskie Voivodeship in which the increase (by PLN 481) relative to the beginning of the previous EU program, took place only in 2014-2015 (respectively $1.5 \%$ and $16 \%$ ). An equally poor situation in terms of growth was in Lubuskie Voivodeship in which the investments were higher than the base year only in 2015, having remained for the whole period below the value from 2007 (in 2014 investments were lower than in 2007 by PLN 711). The worst negative level of investment was among enterprises in Świętokrzyskie Voivodeship. Until 2012, enterprises in that region had maintained a positive growth rate with a range of $16 \%$ to $30 \%$. However, from 2013 they were below the 2007 level in the range from PLN 62 to PLN 301.

The above data show how varied the scale of investment among Polish enterprises in regional terms was and how much it is necessary to implement effective mechanisms that would be able to remedy this. Support for enterprises under the EU's cohesion policy should lead to an improvement in the level of entrepreneurship in these regions. At the same time, however, it is necessary to strongly emphasise the enormous effort made by enterprises nationwide by higher investment. This has had a definite impact on the level of added value and the share of GDP generated by the private sector, despite the two crises that companies faced over those nine years.

\section{Summary}

Both the SME sector and large businesses play a significant role in national economic development with a considerable contribution to the creation of GDP at a level close to $75 \%$. Particular attention was paid to small and medium-sized enterprises both nationally and in the EU. This is due to the significant impact on the competitiveness of the economy and employment, contributing to development in the socio-economic dimension, especially at the regional level.

At the same time, it should be noted that development opportunities for the economy and enterprises themselves are a way of investment. They are one of the main components of GDP behind only household expenditure, government expenditure and net exports. The development of a company and the chance to compete with other market players, as well as building a strong economy, is impossible without capital expenditure. Investments are designed to move a company to a higher position against other businesses, contributing to increased economic benefits. The increase in corporate investment from both a regional and national perspective is evidence of the sound financial condition of businesses and a positive signal about the state of the economy while giving information about its development. 
Despite growing investment among Polish enterprises, compared to the rest of the EU the value of expenditure on fixed assets is still low. The average value made in the private sector per enterprise in Poland in 2015 was PLN 30 000, while the average value among EU countries was up to $70 \%$ higher. However, it is necessary to emphasise the growing level of investment value among private businesses for over nine years. The total level of investment in Poland in 2015 amounted to PLN 200.6 billion; in relation to 2007, it was an increase of as much as 39\%. In turn, the value of the SME sector was nearly PLN 90 billion, of which medium-sized enterprises played the dominant role.

The investment rate indicator describing the ratio of gross fixed capital formation to GDP amounted to $20.1 \%$ in 2015 , which placed Poland in $15^{\text {th }}$ place in Europe. This result was slightly higher than the EU average, where for the 28 member states this ratio was $19.9 \%$. Throughout the period under review, i.e. 2007-2015, the level of public sector investment was always higher than the EU-28 average, something never achieved in the private sector. However, paying attention to private sector investments only, they account for about $80 \%$ of the total level of expenditure on fixed assets in relation to GDP.

In the regional system, in five voivodeships at the end of 2015, there was an increase in the investment rate in relation to 2007. On the other hand, in the remaining eleven regions, the indicator had decreased compared to the base year. At the same time, a wide regional diversity was found in the level of investment growth per capita at working age over the years 2007-2015. The most significant increase was in Lubelskie Voivodeship (85\%) and the worst in Świętokrzyskie Voivodeship. This happened, despite the enterprises of that region having positive growth until 2012.

Structurally, large enterprises had a dominant role in terms of the value of investment (55\%) among all businesses due to their size. Within the SME sector itself, medium-sized enterprises $(45 \%)$ had a dominant share, followed by micro-enterprises over small-scale businesses. In regions where the level of investment was lowest in absolute terms, the share of the SME sector also reached the level of 60-70\% over investments made by large businesses. In terms of business type, investments in industry, especially industrial processing, had the largest share (over 50\%).

The growth of investment among small and medium-sized enterprises in Poland in relation to 2007 amounted to $30 \%$, of which micro-enterprises took as much as $62 \%$. At the end of 2015, the level of investments per enterprise in the SME sector had quite clearly increased to the value of PLN 47000 (an increase of 21\%). Among the regions with the highest investment rate in 2015, four out of five voivodeships were in the eastern borderland. These were also areas where, unfortunately, the level of entrepreneurship has remained below the national average. For many years, these regions stood out from others due to the lack of significant investments. Since Poland acceded to the EU, intensive activities have been carried out at national and regional levels to significantly improve the socio-economic development in the areas that make up the eastern border of the entire EU. It can be said that this situation is somewhat similar to that which occurs in the eastern Länder of Germany. Therefore, higher values of investment at the end of 2015 mean visible progress for the development of the regions of eastern Poland.

Therefore, it seems crucial to promote all kinds of support mechanisms that would be able to reduce disparities in the level of development of enterprises and their investment expenditures in relation to other EU states, as well as between regions within Poland. 


\section{References}

Bień, W. (2000). Zarządzanie finansami przedsiębiorstwa. Warszawa: Difin.

Borowiecki, R. (ed.). (2009). Pomiar i ocena procesów kreowania wartości w badaniu efektywności przedsiębiorstwa. Kraków: Fundacja Uniwersytetu Ekonomicznego.

Czyżowska, J. (2014). Wybrane makroekonomiczne uwarunkowania decyzji inwestycyjnych polskich przedsiębiorstw. Przedsiębiorstwo \& Finanse, 2(5), 15-25.

Firlej, K.A. (2019). Expenditure on research and development activities as a determinant of the innovativeness of the European Union's economy. Research Papers of Wrockaw University of Economics, 63(7), 35-46. doi.org/10.15611/pn.2019.7.03

GUS. (2018). Działalność przedsiębiorstw niefinansowych w 2017 roku. Warszawa: GUS.

GUS. (2016a). Środki trwałe w gospodarce narodowej w 2015 roku. Warszawa: GUS.

GUS. (2016b). W drodze do spójności. Polskie regiony 2007-2013. Warszawa: GUS.

GUS. (2013). Warunki powstania i działania oraz perspektywy rozwojowe polskich przedsiębiorstw powstatych $w$ latach 2001-2013. Warszawa.

Obłój, K. (2007). Strategia organizacji. Warszawa: PWE.

Piątkowski, M.J. (2020). Results of SME Investment Activities: A Comparative Analysis among Enterprises Using and Not Using EU Subsidies in Poland. Administrative Sciences, 10(1), 1-26. doi.org/10.3390/admsci10010004

Piątkowski, M.J. (2013). Czynniki wzmacniające pozycję konkurencyjną i rozwój przedsiębiorstw. In: K. Zieliński (ed.), Makroekonomiczne i sektorowe czynniki rozwoju przedsiębiorczości. Katowice: Wydawnictwo Naukowe "Śląsk", 193-217.

Piątkowski, M.J. (2010). The impact of cohesion policy of the European Union to employment growth and economic development. Implications for Poland. Organization and Management, 142(4), 8399. doi.org/276277047

Reilly, F.K., Brown, K.C. (2011). Investment analysis and portfolio management. Florence, KY, United States: Cengage Learning, Inc.

Rębilas, R. (2014). Finansowanie inwestycji przedsiębiorstw. Warszawa: Difin.

Rogowski, W. (2011). Metodyka rachunku opłacalności inwestycji: zasady i korzyści inwestycji. In: S. Wrzosek (ed.), Finanse - nowe wyzwania teorii i praktyki. Finanse przedsiębiorstw. Wrocław: Wydawnictwo Uniwersytetu Ekonomicznego we Wrocławiu, 188-190.

Skica, T., Bem, A., Żygadło, K. (2013). The role of local government in the process of entrepreneurship development. Financial Internet Quarterly, 9(4), 1-24.

Suszyński, C. (2007). Wyzwania na poziomie przedsiębiorstwa - imperatyw tworzenia wartości. In: C. Suszyński (ed.), Przedsiębiorstwo: wartość, zarządzanie. Warszawa: PWE, 88-111.

Wildowicz-Giegel, A. (2013). Investment Priorities and the Innovation of Enterprises in Poland. Oeconomia Copernicana, 4(1), 65-77. doi.org/10.12775/OeC.2013.005

Żurek, J. (2003). Istota inwestycji oraz decyzje inwestycyjne i ich rola w rozwoju przedsiębiorstwa. In: J. Żurek (ed.), Ekonomika i kierowanie rozwojem przedsiębiorstwa. Gdańsk: Fundacja Rozwoju Uniwersytetu Gdańskiego, 364-369.

Marcin J. Piątkowski, PhD in economics, assistant professor in the Department of Entrepreneurship and Innovation of the Cracow University of Economics (Poland). Head of own research grants and author of academic publications in the field of entrepreneurship, competitiveness and development of enterprises (especially SMEs), investment activity of enterprises as well as European funds and EU cohesion policy. His research interests also include aspects related to the issue of Industry 4.0 and the use of information technologies in business management, purchasing processes and relations between companies and customers. He has given guest lectures at foreign universities: University of Valencia, University of Alicante, ISCTE in Lisbon, University of Pablo de Olavide (Seville), University of Málaga, University of Balearic Islands and completed a teaching internship at 
the University College London. He is a certified academic tutor and expert in national and regional operational programs of EU funds for 2014-2020.

ORCID: https://orcid.org/0000-0001-7195-3827

\section{Address:}

Uniwersytet Ekonomiczny w Krakowie

Katedra Przedsiębiorczości i Innowacji

ul. Rakowicka 27

31-510 Kraków, Polska

e-mail: marcin.piatkowski@uek.krakow.pl 